\title{
Covid-19 Pandemi Sürecinde Bireylerin Sosyal Destek ve Aile İklimi Algılarının Incelenmesi
}

\section{Investigation of Individuals' Perception of Social Support and Family Climate During Covid-19 Pandemic}

\author{
Zekavet KABASAKAL , Doç. Dr., Dokuz Eylül Üniversitesi, Eğitim Fakültesi, İzmir/Türkiye, \\ zekavetkabasakal@gmail.com
}

Aykut AKTAŞ $^{\text {(D) }}$,Psikolojik Danışman, Milli Eğitim Bakanlığı, İzmir/Türkiye, aykutaktas@hotmail.com

\begin{abstract}
Kabasakal, Z. ve Aktaş, A. (2021). Covid-19 Pandemi Sürecinde Bireylerin Sosyal Destek ve Aile İklimi Algılarının İncelenmesi. Batı Anadolu Eğitim Bilimleri Dergisi, 12 (1), 145-157.

Geliş tarihi: 06.04.2021

Kabul tarihi: 03.05.2021

Yayımlanma tarihi: 28.06 .2021
\end{abstract}

Öz. Bu çalışmanın amacı Covid-19 pandemisi sürecinde bireylerin sosyal destek ve aile iklimi algılarının çeşitli sosyodemografik ve Covid-19'la ilişkili çeşitli değişkenler açısından incelenmesidir. Katılımcılar araştırmaya gönüllülük esasına göre Google formlar aracılığıyla katılmıştır. Çalışma grubu uygun örneklemeyle oluşturulan 684 kişiden oluşmaktadır. Araştırmanın yöntemi ilişkisel tarama modelindedir. Araştırma kapsamında veriler Kişisel Bilgi Formu, Çok Boyutlu Algılanan Sosyal Destek Ölçeği'nin Gözden Geçirilmiş Formu ve Algılanan Aile İklimi Ölçeği aracılığıyla elde edilmiştir. Araştırma bulguları incelendiğinde evli katılımcıların aileden sağlanan sosyal destek, aile içi ilişkisellik ve bilişsel uyum boyutları ortalama puanlarıın, bekar katılımcıların ortalamalarından daha yüksek olduğu bulunmuştur. Aileden, arkadaştan ve özel bir insandan sağlanan destek boyutu ile aile içi ilişkisellik boyutu arasında pozitif yönlü, kuşaklararası otorite boyutu ile negatif yönlü ilişkili olduğu görülmüştür. Aileden sağlanan destek, ve özel bir insandan sağlanan destek boyutları ile bilişsel uyum alt boyutu arasında pozitif yönlü anlamlı ilişkiler bulunmuştur. Aileden, arkadaştan ve özel bir insandan sağlanan destek puanları birlikte, aile içi ilişkisellik alt boyutundaki varyansın \% 49'unu, kuşaklararası otorite alt boyutundaki varyansın \% 5'ini ve bilişsel uyum alt boyutundaki varyansın \% 22 'sini açıklamaktadır. Çalışmada elde edilen bulgular ilgili literatür ışı̆̆ında tartışıımışırır.

Anahtar Kelimeler: Pandemi, Covid-19, Aile iklimi, Sosyal destek

\begin{abstract}
The aim of this study is to examine individuals' perceptions of social support and family climate during the Covid-19 pandemic process in terms of various sociodemographic and variables related to Covid-19. The participants of this study are 684 adults ( 181 male, 495 female and 8 not specified) over 18 years old. This research is based on the relational screening model. The Personal Information Form, the Revised Form of the Multidimensional Perceived Social Support Scale and Perceived Family Climate Scale were used to collect research data. The married participants' mean scale scores in the dimensions of support from family, relatedness in family, and cognitive cohesion were higher than the single participants' mean scale scores. There is a link between Perceived Social Support and Family Climate. The scores of support from the family, support from a friend and support from a special person together accounted for $49 \%$ total of the variance in relatedness in family score. The scores of support from the family, support from a friend and support from a special person together accounted for $49 \%$ total of the variance in intergenerational authority score. The scores of support from the family, support from a friend and support from a special person together accounted for $49 \%$ total of the variance in cognitive cohesion score. The results of this study were examined in the context of the related literature.
\end{abstract}

Keywords: Pandemic., Covid-19, Family climate, Social support. 


\section{Extended Abstract}

Introduction. The Covid-19 pandemic, which began in Wuhan city, China at the end of 2019, has caused radical changes in many areas of life. Quarantine decisions taken for the health of the public during the pandemic can be expected to have consequences in many different areas. It is stated that if the quarantine period lasts longer than 10 days, individuals' psychological well-being may be affected negatively and quarantine may lead to some psychological problems. The need for social support is quite high during adverse events such as a pandemic. Individuals' social support resources play an important role in preventing the occurrence of stressful life events. In addition, these resources help to protect psychological and physical health (Patterson, 1992; Pengilly and Dowd, 2000).

A person's family is one of his most significant sources of social support. Family characteristics can be both protective or risk factors for the individual. Relatedness in family, intergenerational authority and cognitive cohesion are sub-dimensions of family climate. It can be expected that the family climate has affected the individual's difficulties during quarantine and their ability to deal with pressures caused by epidemics. Through this study, it was aimed to examine the social support and family climate perceptions of individuals during the pandemic in terms of some variables related to the epidemic and sociodemographic variables.

Method. This research is based on the relational screening model. A relational screening model is one that attempts to assess the presence or degree of covariance between two or more variables. (Büyüköztürk, Çakmak, Akgün, Karadeniz and Demirel, 2017). The study group consists of 684 participants over the age of 18 determined through appropriate sampling (181 males, 495 females, 8 not specified). The study data was gathered using Google forms for the Personal Information Form, Multidimensional Perceived Social Support Scale Revised Form, and Perceived Family Climate Scale. Correlation tables regarding Multidimensional Perceived Social Support Scale and Family Climate Scale are given. Findings regarding the prediction of family climate were obtained by regression analysis. The study group's descriptive statistical findings were also reported.

Results. The married participants' mean scores on the dimensions of support from the family, relatedness in family, and cognitive cohesion were higher than the single participants' mean scores. There is a link between Perceived Social Support and Family Climate. The scores of support from the family, support from a friend and support from a special person together accounted for $49 \%$ total of the variance in relatedness in family score $(R=.702 ; R 2=.493 ; p<.001)$. The scores of support from the family, support from a friend and support from a special person together accounted for $49 \%$ total of the variance in intergenerational authority score $(R=.231 ; R 2=.053 ; p<.001)$. The scores of support from the family, support from a friend and support from a special person together accounted for $49 \%$ total of the variance in cognitive cohesion score $(R=.471 ; R 2=.222 ; p<.001)$.

Discussion and Conclusion. In this study, it was aimed to evaluate the relationship between social support perception and family climate of adults during Covid-19 pandemic. The majority of the working group consists of women. The rates of married and single participants are close to each other. The average scores of support from family, support from a friend, support from a special person, relatedness in family and cognitive cohesion did not significantly differ depending on the participants' gender. Altay and AvcI (2009) also reported in their study that the perceived social support from the family does not differ according to gender. In the study conducted by Turgut (2019), it was stated that the cognitive adjustment sub-dimension of the family climate did not differ according to gender, while the sub-dimensions of inter-family relationality and intergenerational authority differ according to gender. Tonsing, Tmet and Tse (2012), in their study conducted with 131 male and 160 female participants to evaluate the psychometric properties of the multidimensional perceived social support scale, stated that the subscales of perceived social support did not differ according to gender. 
Pandemic appears to have the potential to have a psycho-social impact on people as well as physical health problems (Subramanian, Gupte, Dorairaj, Periannan \& Mathai 2009). In difficult life events, it is observed that individuals get closer to their relatives and friends, seek support from them and formulate coping strategies in this way (Folkman ve Lazarus, 1980; Ysseldyk, R., Matheson, K. \& Anisman 2011). It was discovered in our research that the average scores of perceived social support and family climate of married individuals were higher. Findings from various studies show that social supports, especially social support from the family, are powerful protective factors for anxiety (Roohafza, 2014; Yasin and Dzulkifli, 2010). We discovered that the scores obtained from all subdimensions of the Family Climate Scale and the Perceived Social Support Scale have positive significant relationships. Supporting the above research data, it can be argued that the existence of individuals' perceptions of social support is related to the family climate.

The social support perceived by the participants from their social environment is seen to predict the sub-dimensions of the family climate scale at different rates. This result shows that the family is one of the important sources of social support. Our study is in line with the study showing that individuals seek the social and emotional support of their relatives and peers to meet their social support needs and also need to spend more time with family members (Cullen, Gulati and Kelly, 2020). Our study also parallels the study that concluded that there is a negative correlation between the mental health problems experienced by individuals and the level of social capital that individuals have during public health crises (Noel, Cork \& White, 2018).

It can be thought that supporting the psycho-social structure of individuals has short and longterm benefits. In Turkey, help books written for children and adolescents during the pandemic focus on the attitudes of family members about the epidemic and activities that the whole family participate in (Ercan, Arman-Rodopman, İnal-Emiroğlu, Öztop \& Yalçın, 2020). During the epidemic, the family climate has been described as a key determinant of adolescents' psychological needs (ArI, 2020). 


\section{Giriş}

2019 yılı sonunda Çin'in Wuhan kentinde başlayarak tüm dünyada etkili olan Covid-19 salgını, iş yaşamından eğitime pek çok yaşam alanında değişikliğe gidilmesine neden olmuştur. Bugün itibariyle dünyada yaklaşık 130 milyon Covid-19 tanılı vaka sayısına ulaşılış̧ır (Dünya Sağı̆ı Örgütü [WHO], 2021). Pandemi sürecinde bireylerin sağlığı için alınan karantina önlemlerinin çok farklı alanlarda sonuçlarının olması beklenebilir. Karantina süresinin 10 günden uzun sürmesi durumunda bireylerin psikolojik iyi oluşlarının etkilenebileceği ve bazı psikolojik sorunlara yol açabileceği aktarılmaktadır (Hawryluck vd., 2004). Bireylerinde evde kalma süreçlerinde aileleri ile daha uzun zaman geçireceği göz önüne alındığında aileye ilişkin özellikler bireyin pandemi sürecini algılamasında ve pandeminin olumsuz etkileri ile başa çıkmasında önemli bir etken olarak görülmektedir. Aileye ilişkin özelliklerin bireyin psikolojik iyi oluşunu etkilediği ve ayrıca bireyin algıladığı sosyal destek ile psikolojik dayanıklılıkları arasında ilişki olduğu bilinmektedir (Akdağ ve Çankaya, 2015; Terzi, 2008).

Sosyal desteğin, ruh sağlığı alanında koruyucu ve baş etmeye yönelik rolü üzerindeki çalışmalar son dönemde ilgi görmekte ve sosyal destekle ilgili çalışmaların daha çok bireylerin sosyal ilişkilerini yeterince destekleyici bulup bulmadıklarıyla ilişkin algılarını konu edindiği görülmektedir (Eker, Arkar ve Yaldız, 2001) Literatür incelendiğinde sosyal destek kavramına ilişkin çok çeşitli tanımların olduğu görülmekle birlikte; bu kavram genel olarak bireyin kişisel hedeflerine ulaşmasında ya da zorluklarla başa çıkma konusunda destek alıyor olduğu ya da aldığı mevcut ve geçmiş etkileşimlerinin bilişselduygusal olarak işlenmesinin sonucu olarak tanımlanabilmektedir (Fydrich ve Sommer, 2003). Sosyal desteğin işlemleştirilmesi bireyin medeni durumu, sosyal kaynaklarının sayısı, dahil olduğu sosyal ağın büyüklüğü gibi nesnel bir şekilde olabileceği gibi algılanan sosyal destek ve kabul edilme duygusu gibi öznel de olabilmektedir (Von Lieres, 2013).

Sosyal desteğe duyulan ihtiyaç, pandemi gibi olumsuz durumlar ve olaylar sırasında oldukça yüksekti. Pandemi durumunda ilan edilen karantina ya da izole yaşam biçimiyle birlikte sosyal destekte yaşanacak kesinti, bireyin bağlantılı olma duygusunu tehdit edici nitelikte olabilir ve ruh sağlığı üzerinde olumsuz sonuçlar yaratabilir (Hawryluck vd., 2004). Bireyin stres yaşamasına neden olabilecek yaşam olaylarının oluşumunu önlemesi açısından sosyal destek kaynakları önemli bir rol oynamaktadır ve psikolojik ve fiziksel sağlığını korumasına yardımcı olmaktadır (Patterson, 1992; Pengilly ve Dowd, 2000). Bireylerin stresli yaşam olayları sırasında ailelerinden ya da arkadaşlarından etkili bir şekilde yardım alacaklarına ilişkin algılarının, düşük majör depresyon (Lakey ve Cronin, 2008) ve travma sonrası stres bozukluğu belirtileri (Brewin, Andrews ve Valentine, 2000) ile ilişkili olduğu görülmüştür. Bununla birlikte ebeveynlerin yüksek sosyal desteğe sahip olmalarının, pozitif ebeveyn-çocuk aktivitelerinde zaman içinde daha fazla artışa neden olduğu ve annelerin algıladıkları sosyal desteğin yakın ilişkilerde yaşadıkları endişe ve kaygıyla ters yönde ilişkili olduğunu göstermektedir (Devoldre, Davis, Verhofstadt \& Buysse, 2010).

Bireyin en önemli sosyal destek kaynaklarından biri de ailesidir. Aileye ilişkin özellikler bireye ait pek çok süreçte koruyucu ya da risk faktörü olarak karşımıza çıkmaktadır. Ailenin sağlıklı olmasının bireyin özgüveni üzerinde etkili olduğunu bilinmektedir (Öztürk, 2017). Aile iklimi kapsamında ailenin uyumu, kuşaklararası ilişkiler ve aileye ilişkin süreçler ele alınmaktadır. Pandemi sürecini pek çok birey ailesi ile geçirmiştir. Aileler bu aşamada bireylerin ana sosyal destek yapılarını oluşturmuşlardır. Aynı zamanda aile ikliminin bireyin karantinada kalma, salgın stresiyle başa çıkma yollarını da etkilemiş olmaları beklenebilir. Bu çerçevede bu araştırmanın amacı pandemi sürecinde bireylerin sosyal destek ve aile iklimi algılarının incelenmesidir. 


\section{Yöntem}

Bu araştırma ilişkisel tarama modeli kullanılarak hazırlanmıştır. Illişkisel model ise araştırmada kullanılan değişkenler arası ilişkinin varlığı ve derecesi açısından incelenmesidir (Çepni, 2010; Karasar, 2005). Araştırma kapsamında çalışma grubuna ait betimsel istatistik sonuçları (katılımcı sayısı, frekans ve yüzdelikler) rapor edilmiştir. Bu çalışmada Çok Boyutlu Algılanan Sosyal Destek Ölçeği ve Aile İklimi Ölçeği'ne ilişkin korelasyon tabloları verilmiştir. Ayrıca regresyon analizleriyle Aile íklimi Ölçeği'nin alt boyutlarına ilişkin varyansın Algılanan sosyal destek alt boyutlarıyla ne oranda açıklandığı araştırılmıştır.

\section{Çalışma Grubu}

Çalışma grubu uygun örnekleme yoluyla oluşturulmuştur. Uygun örnekleme; kısıtlı olanaklar içerisinde örneklemin ulaşılabilirliğinin kolay ve uygulama yapılabilir olması şeklinde tanımlanabilir. (Fraenkel, Wallen ve Hyun, 2012). Araştırmada çalışmaya katılmaya gönüllü olan 18 yaş üstü bireylerle çalışımıştır. Sokağa çıkma kısıtlaması gibi önlemlerin alındığı ve evde kalmanın teşvik edildiği pandemi sürecinde, çalışma hakkında sosyal medya hesaplarından bilgi verilmiş ve ulaşılan kişilerden de çalışmayı çevrelerine duyurmaları istenmiştir. Bu sürecin sonun 684 kişi çalışmaya katılmaya gönüllü olmuş ve veriler katılımcılardan Google formlar aracılığıyla toplanmıştır. Çalışma grubuna ilişkin betimsel istatistikler bulgular kısmında sunulmuştur.

\section{Veri Toplama Araçları}

\section{Çok Boyutlu Algılanan Sosyal Destek Ölçeği'nin Gözden Geçirilmiş Formu}

Ölçek 12 madeden oluşan 7 li likert tipinde bir ölçektir. Her bir madde kesinlikle hayır (1) ve kesinlikle evet (7) arasında puanlanmaktadır. Ölçek, bireylerin destek alabileceği kaynakları yansıtmak üzere 3 alt boyuta sahiptir. Bu alt boyutlar, aileden, arkadaştan ve özel bir kişiden sağlanan desteği ifade etmektedir. Her bir alt boyuttan en az 4, en fazla 28 puan alınabilir. Ölçekten yüksek puan elde edilmesi, algılanan sosyal desteğin yüksek olduğunu göstermektedir (Eker vd., 2001).

\section{Algılanan Aile Iklimi Ölçeği}

Aile yapısının bireyler üstündeki etkisini ölçmeyi amaçlamaktadır. Bu ölçüm aracı ile aile mekanizmaları geniş aile bağlamında ele alınmıştır ve kuşaklar arası değer ve biliş aktarımına dair bilgi edinebilmek mümkündür. Üç alt boyuttan oluşmaktadır. Aile içi ilişkisellik (21 madde), Kuşaklararası otorite ( 7 madde), Bilişsel uyum (6 madde). Ölçek 5'Likert tipi bir ölçektir. Her bir madde 1'den (kesinlikle katılmıyorum), 5'e kadar (kesinlikle katılıyorum) puanlanabilmektedir. Ölçeğin Cronbach Alpha iç tutarlık güvenirlik katsayısı 34 madde için .91 olarak bulunmuştur (Gönül, Baş ve Acar, 2018).

\section{Kişisel Bilgi Formu}

Çalışmanın amacına uygun olarak araştırmacılar tarafından hazırlanmıştır. Kişisel bilgi formunda katılımcılara ilişkin demografik bilgi soruları ve Covid-19 pandemi süreci ile ilgili sorular yer almaktadır.

\section{Araştırma Etiği}

Bu araştırmanın planlanmasından, uygulanmasına, verilerin toplanmasından verilerin analizine kadar olan tüm süreçte "Yükseköğretim Kurumları Bilimsel Araştırma ve Yayın Etiği Yönergesi" kapsamında uyulması belirtilen tüm kurallara uyulmuştur. Yönergenin ikinci bölümü olan "Bilimsel 
Araştırma ve Yayın Etiğine Aykırı Eylemler" başlığı altında belirtilen eylemlerden hiçbiri gerçekleştirilmemiştir. Bu çalışmanın yazım sürecinde bilimsel, etik ve alıntı kurallarına uyulmuş; toplanan veriler üzerinde herhangi bir tahrifat yapılmamış ve bu çalışma herhangi başka bir akademik yayın ortamına değerlendirme için gönderilmemiştir.

\section{Etik Kurul İzin Bilgileri}

Etik değerlendirmeyi yapan kurul adı: T.C. Dokuz Eylül Üniversitesi Sosyal ve Beşeri Bilimler Araştırma ve Yayın Etik Kurulu

Etik değerlendirme kararının tarihi: 14/07/2020

Etik değerlendirme belgesi sayı numarası: 87347630/42104268/2990

\section{Bulgular}

Tablo 1.

Araştırma grubuna ilişkin betimsel istatistikler

\begin{tabular}{|c|c|c|c|}
\hline Değişken & Gruplar & $\boldsymbol{F}$ & $\%$ \\
\hline \multirow{6}{*}{ Yaş } & $18-25$ & 257 & 37,6 \\
\hline & $26-35$ & 201 & 29,4 \\
\hline & $36-45$ & 137 & 20,0 \\
\hline & $46-55$ & 61 & 8,9 \\
\hline & $56-65$ & 20 & 2,9 \\
\hline & $65+$ & 8 & 1,2 \\
\hline \multirow{3}{*}{ Cinsiyet } & Erkek & 181 & 26,5 \\
\hline & Kadın & 495 & 72,3 \\
\hline & Belirtmek İstemiyorum & 8 & 1,2 \\
\hline \multirow{6}{*}{ Eğitim Durumu } & Okur-Yazar & 20 & 2,9 \\
\hline & İlkokul Mezunu & 9 & 1,3 \\
\hline & Ortaokul Mezunu & 14 & 2,0 \\
\hline & Lise Mezunu & 126 & 18,4 \\
\hline & Önlisans/Lisans Mezunu & 417 & 61,0 \\
\hline & Yüksek Lisans/Doktora Mezunu & 98 & 14,3 \\
\hline \multirow{7}{*}{ Gelir } & 1000 TL'nin altında & 14 & 2,0 \\
\hline & $1001-2000$ & 45 & 6,6 \\
\hline & 2001-3000 & 76 & 11,1 \\
\hline & $3001-5000$ & 161 & 23,5 \\
\hline & $5001-7000$ & 149 & 21,8 \\
\hline & $7001-10000$ & 136 & 19,9 \\
\hline & 10000 TL'nin üzerinde & 103 & 15,1 \\
\hline \multirow{3}{*}{ Medeni Durum } & Evli & 307 & 44,9 \\
\hline & Bekar & 361 & 52,8 \\
\hline & Diğer & 16 & 2,3 \\
\hline \multirow{4}{*}{$\begin{array}{l}\text { Çocuğa Sahip } \\
\text { Olma Durumu }\end{array}$} & Yok & 420 & 61,4 \\
\hline & 18 yaş altında çocuğum/çocuklarım var & 186 & 27,2 \\
\hline & 18 yaş altında ve üstünde çocuklarım var & 25 & 3,7 \\
\hline & 18 yaş üstünde çocuğum/çocuklarım var & 53 & 7,7 \\
\hline \multirow{7}{*}{ Meslek } & İ̧̧siz & 33 & 4,8 \\
\hline & Öğrenci & 220 & 32,2 \\
\hline & Emekli & 30 & 4,4 \\
\hline & İşçi & 15 & 2,2 \\
\hline & Memur & 30 & 4,4 \\
\hline & Öğretmen/Akademisyen & 233 & 34,1 \\
\hline & Sağlık çalışanı & 59 & 8,6 \\
\hline
\end{tabular}




\begin{tabular}{llrr}
\hline & Çiftçi/Hayvancılık & 2 & 12 \\
& Esnaf/serbest çalışan/ticaret & 12 & 1,8 \\
& Diğer & 50 & 7,3 \\
\hline & Yalnız yaşıyorum & 56 & 8,2 \\
& Anne, baba ve kardeşlerden en az biriyle & 286 & 41,8 \\
& Eşimle/romantik ilişkide olduğum partnerimle & 78 & 11,4 \\
Kiminle Yaşıyor & Eşimle, çocuk ve/veya çocuklarımla & 223 & 32,6 \\
& Çocuk ve/veya çocuklarımla & 15 & 2,2 \\
& Arkadaş/arkadaşlarımla & 14 & 2,0 \\
& Diğer & 12 & 1,8 \\
\hline & Salgın öncesinde çalışmıyordum, yine çalışmıyorum & 239 & 34,9 \\
& Salgın öncesinde çalışıyordum, şimdi çalışmıyorum & 123 & 18,0 \\
Çalışma Durumu & 204 & 29,8 \\
& Evden çalışıyorum & 54 & 7,9 \\
& Bazen evde, bazen iş yerinde çalışıyorum & 64 & 9,4 \\
\hline Covid-19 tedavisi & Sürekli iş yerine giderek çalışıyorum & 577 & 84,4 \\
gören tanıdık & Evet, var & 107 & 15,6 \\
\hline Covidden ölen & Hayır, yok & 639 & 93,4 \\
tanıdık & Evet, var & 45 & 6,6 \\
\hline
\end{tabular}

Araştırma grubuna ilişkin betimsel istatistiklere bakıldığında örneklem grubunun $\% 26,5^{\prime} \mathrm{i}$ erkeklerden, 72,3'ü kadınlardan oluşmaktadır. Katılımcıların \%1,2'si ise cinsiyetlerini belirtmek istememişlerdir. Katılımcıların yaş gruplarına ilişkin frekans ve yüzdelik değerlere bakıldığında, 18-25 yaş aralığında 257 (\% 37,6), 26-35 yaş aralığında 201 (\%29,4), 36-45 yaş aralığında 137 (\%20), 46-55 yaş aralığında $61(\% 8,9), 56-65$ yaş aralığında $20(\% 2,9)$ ve 65 yaş ve üzerinde ise $8(\% 1,2)$ kişinin bulunduğu görülmektedir. Çalışma grubunun \%2,9'u okur-yazar, \%1,3'ü ilkokul mezunu, \%2'si ortaokul mezunu, $\% 18,4$ 'ü lise mezunu, $\% 61$ 'i önlisans/lisans mezunu ve \%14,3'ü ise yüksek lisans/doktora mezunu olduklarını belirtmişlerdir.

Katılımcıların beyan ettikleri ailelerine ait toplam aylık gelirleri incelendiğinde, çalışma grubunun \%2'sinin 1000 TL'nin altında, \%6,6'sının 1001-2000 TL aralığında, \%11,1'inin 2001-3000 TL aralığında, \%23,5'inin 3001-5000 TL aralığında, \%21,8' inin 5001-7000 TL aralığında, \%19,9' unun 7000110000 TL aralığında ve $\% 15,1$ 'inin 10.000 TL'nin üzerinde aylık aile gelirine sahip oldukları görülmüştür. Katılımcıların medeni durumlarına bakıldığında ise, katılımcıların \%44,9'unun evli ve \%52,8'inin bekar olduğu görülmektedir. Katılımcıların \%2,3’ü ise medeni durumlarını diğer olarak belirtmişlerdir.

Katılımcıların \%61,4'ü çocuğu olmadığını, \%27,2'si 18 yaş altında çocuğu/çocukları olduğunu, \% 3,7'si 18 yaş altında ve üstünde çocukları olduğunu ve \%7,7'si 18 yaş üstünde çocuğu/çocukları olduğunu belirtmişlerdir. Katılımcıların mesleklerine bakıldığında, \%4,8'inin işsiz, \%32,2'sinin öğrenci, \%4,4'ünün emekli, \%2,2'sinin işçi, \%4,4'ünün memur, \%34,1'inin öğretmen/akademisyen, \%8,6'sının sağ ıık çalışanı, \%0,3'ünün çiftçi/hayvancılık, \%1,8'inin esnaf/serbest çalışan/tüccar ve \%7,3'ünün diğer meslek dallarında olduğu görülmüştür.

Katılımcıların ikamet durumlarına bakıldığında ise $\% 8,2^{\prime}$ sinin yalnız, $\% 41,8$ 'inin anne, baba ve kardeşlerden en az biriyle, \%11,4'ünün eşiyle/romantik ilişkide olduğu partneriyle, \%32,6'sının eşiyle, çocuk ve/veya çocuklarıyla, \%2,2'sinin çocuk ve/veya çocuklarıyla, \%2'sinin arkadaş/arkadaşlarıyla yaşadığı görülmektedir. Katılımcıların $\% 1,8^{\prime} i$ ise ikamet ettikleri yer sorusuna diğer seçeneğini işaretleyerek cevap vermişlerdir.

Katılımcıların Covid-19 pandemisi ülkemizde görülmeye başladığı tarihten itibaren çalışma durumlarına bakıldığında \%34,9'unun Salgın öncesinde çalışmıyordum, yine çalışmıyorum seçeneğini, $\% 18$ 'inin salgın öncesinde çalışıyordum, şimdi çalışmıyorum seçeneğini, \%29,8'inin evden çalışıyorum 
seçeneğini, \%7,9'unun bazen evde, bazen iş yerinde çalışıyorum seçeneğini, \%9'4ünün Sürekli iş yerine giderek çalışıyorum seçeneğini işaretledikleri görülmüştür.

Katılımcıların covid19 salgını sürecinde sağlık bakanlığı tarafından belirtilen kronik hastalıklardan birine sahip olup olmadıklarına bakıldığında, katılımcıların \%81,3'ünün hayır, yok, $\% 14,3^{\prime}$ ünün evet, var ve \%4,4'ünün bilmiyorum seçeneğini işaretledikleri görülmektedir. Katılımcıların covid19 salgını sürecinde yakınlarının sağlık bakanlığı tarafından belirtilen kronik hastalıklardan birine sahip olup olmadıkları incelendiğinde, katılımcıların \%43,3'ünün hayır, yok, $\% 52,2$ 'sinin evet, var ve \%4,5'inin bilmiyorum seçeneğini işaretledikleri görülmektedir. Katılımcıların \%23,1'inin Covid-19 pozitif olan tanıdıklarının olduğu, \%15,6'sının Covid-19 nedeniyle tedavi gören tanıdıklarının olduğu ve $\% 6,6$ 'sının covid19 nedeniyle hayatını kaybeden tanıdıklarının olduğu görülmüştür.

Tablo 2.

Katılımcıların algılanan sosyal destek ve aile iklimi düzeylerinin medeni durumları açısından karşılaştııılmasına ilişkin t-Testi Sonuçları

\begin{tabular}{|c|c|c|c|c|c|c|c|}
\hline $\begin{array}{l}\text { Bağımlı } \\
\text { Değişken }\end{array}$ & Medeni Durum & $N$ & $\bar{X}$ & Ss & $t$ & $s d$ & $p$ \\
\hline \multirow{2}{*}{$\begin{array}{l}\text { Aileden sağlanan } \\
\text { destek }\end{array}$} & Evli & 307 & 6,1555 & 1,20305 & \multirow{2}{*}{5,643} & \multirow{2}{*}{666} & \multirow{2}{*}{, $000^{*}$} \\
\hline & Bekar & 361 & 5,5914 & 1,35540 & & & \\
\hline \multirow{2}{*}{$\begin{array}{l}\text { Arkadaştan sağlanan } \\
\text { destek }\end{array}$} & Evli & 307 & 5,6857 & 1,42132 & \multirow{2}{*}{,- 787} & \multirow{2}{*}{666} & \multirow{2}{*}{, 432} \\
\hline & Bekar & 361 & 5,7687 & 1,30457 & & & \\
\hline \multirow{2}{*}{$\begin{array}{l}\text { Özel bir insandan } \\
\text { sağlanan destek }\end{array}$} & Evli & 307 & 4,8787 & 1,98002 & \multirow{2}{*}{1,261} & \multirow{2}{*}{666} & \multirow{2}{*}{,202 } \\
\hline & Bekar & 361 & 4,6766 & 2,13221 & & & \\
\hline \multirow{2}{*}{ Aile içi ilişkisellik } & Evli & 307 & 4,2362 & ,57244 & \multirow{2}{*}{5,953} & \multirow{2}{*}{662,201} & \multirow{2}{*}{,000* } \\
\hline & Bekar & 361 & 3,9604 & ,62422 & & & \\
\hline \multirow{2}{*}{ Kuşaklararası otorite } & Evli & 307 & 2,6487 & ,63983 & \multirow{2}{*}{$-1,309$} & \multirow{2}{*}{654,787} & \multirow{2}{*}{ 192 } \\
\hline & Bekar & 361 & 2,7147 & 66039 & & & \\
\hline \multirow{2}{*}{ Bilişsel Uyum } & Evli & 307 & 3,4218 & ,65848 & \multirow{2}{*}{4,945} & \multirow{2}{*}{666} & \multirow{2}{*}{, $000 *$} \\
\hline & Bekar & 361 & 3,1353 & ,81381 & & & \\
\hline
\end{tabular}

${ }^{*} p<, 001$

Tablo 2'ye göre aileden sağlanan destek ortalama puanları, katılımcıların medeni durumuna göre anlamlı bir farklıık göstermektedir $\left[\mathrm{t}_{(666)}=5,643, \mathrm{p}<.001\right]$. Evli katılımcıların aileden sağladıkları destek ortalama puanları $(\bar{X}=6,1555)$, bekâr olanlardan $(\bar{X}=5,5914)$ daha yüksektir. Katılımcıların aile içi ilişkisellik ortalama puanları, medeni durumları açısından anlamlı bir farklılık göstermektedir $\left[\mathrm{t}_{(662,201)}=\right.$ 5,953, $p<.001]$. Evli katılımcıların aile içi ilişkisellik ortalama puanları $(\bar{X}=4,2362)$, bekâr katılımcılardan $(\bar{X}=3,9604)$ daha yüksektir. Bilişsel uyum ortalama puanları, katılımcıların medeni durumu açısından anlamlı bir farklılık göstermektedir $\left[\mathrm{t}_{(666)}=4,945, p<.001\right]$. Evli katılımcıların bilişsel uyum ortalama puanları $(\bar{X}=3,4218)$, bekâr olanlardan $(\bar{X}=3,1353)$ daha yüksektir.

Tablo 3.

Aile iklimi ölçeği ve algılanan sosyal destek ölçeğinin alt boyutlarına ilişkin korelasyon değerleri

\begin{tabular}{|c|c|c|c|c|c|c|}
\hline & 1 & 2 & 3 & 4 & 5 & 6 \\
\hline 1. Aileden sağlanan destek & 1 & & & & & \\
\hline 2. Arkadaştan sağlanan destek &, $424 * *$ & 1 & & & & \\
\hline $\begin{array}{l}\text { 3. Özel bir insandan sağlanan } \\
\text { destek }\end{array}$ &, $372 * *$ & , $448 * *$ & 1 & & & \\
\hline 4. Aile içi ilişkisellik & ,700** &, $245^{* *}$ & ,249** & 1 & & \\
\hline 5. Kuşaklararası otorite &,$- 231 * *$ &,$- 113^{* *}$ &,$- 084^{*}$ &,$- 209 * *$ & 1 & \\
\hline 6. Bilişsel Uyum &, $450 * *$ &, 069 &, $102 * *$ &, $585^{* *}$ &,$- 110 * *$ & 1 \\
\hline
\end{tabular}


Tablo 3 'e göre Aile İklimi Ölçeği ve Algılanan Sosyal Destek Ölçeğinin alt boyutlarından elde edilen puanlar arasında anlamlı ilişkilerin olduğu görülmektedir. Aile iklimi ölçeğinin aile içi ilişkisellik alt boyutu ile algılanan sosyal destek ölçeğinin aileden sağlanan destek, arkadaştan sağlanan destek ve özel bir insandan sağlanan destek alt boyutları arasında pozitif yönlü anlamlı ilişkilerin olduğu (sırasıyla, $r=.700, p<.01 ; r=.245, p<.01 ; r=.249, p<.01)$ görülmüştür.

Aile iklimi ölçeğinin kuşaklararası otorite alt boyutu ile algılanan sosyal destek ölçeğinin aileden sağlanan destek, arkadaştan sağlanan destek ve özel bir insandan sağlanan destek alt boyutları arasında negatif yönlü anlamlı ilişkilerin olduğu (sırasıyla, $r=-.231, p<.01 ; r=-.113, p<.01 ; r=-.084, p<.05$ ) görülmüştür. Aile iklimi ölçeğinin bilişsel uyum alt boyutu ile algılanan sosyal destek ölçeğinin aileden sağlanan destek ve özel bir insandan sağlanan destek alt boyutları arasında pozitif yönlü anlamlı ilişkilerin olduğu (sırasıyla, $r=.450, p<.01 ; r=.102, p<.01$ ) görülmüştür.

Tablo 4.

Aile içi ilişkiselliğin yordanmasına ilişkin çoklu regresyon analizi sonuçları

\begin{tabular}{|c|c|c|c|c|c|c|c|}
\hline Değişken & B & $\begin{array}{r}\text { Standart } \\
\text { Hata }_{B} \\
\end{array}$ & B & $t$ & $\boldsymbol{P}$ & ikili r & Kısmir \\
\hline Sabit & 2,284 & 087 & & 26,174 & ,000 & & \\
\hline Aileden sağlanan destek & ,336 & ,014 & ,724 & 23,414 & ,000 & 700 & 668 \\
\hline $\begin{array}{l}\text { Arkadaştan sağlanan destek } \\
\text { Özel bir insandan sağlanan }\end{array}$ &,- 030 & 014 &,- 067 & $-2,097$ & ,036 & 245 &,- 080 \\
\hline destek & ,003 & ,009 & ,010 & ,332 & ,740 & 249 & 013 \\
\hline $\begin{array}{lr}R=.702 & R^{2}=.493 \\
F_{(3,680)}=220.419, & p=.000\end{array}$ & & & & & & & \\
\hline
\end{tabular}

Tablo 4 incelendiğinde aile içi ilişkiselliğin yordanmasına ilişkin kurulan regresyon modelinin anlamlı olduğu görülmüştür $\left(F_{(3,680)}=220.419, p<.001\right)$. Başka bir ifadeyle algılanan sosyal destek puanları birlikte aile içi ilişkisellik puanını anlamlı olarak yordamaktadır. Aileden sağlanan destek, arkadaştan sağlanan destek ve özel bir insandan sağlanan destek puanları birlikte aile içi ilişkisellik puanındaki değişimin \% 49'unu açıklamaktadır $\left(R=.702 ; R^{2}=.493 ; p<.001\right)$.

Tablo 4 'te yer alan ikili ve kısmi korelasyonlar incelendiğinde, aile içi ilişkisellik puanı ile aileden sağlanan destek puanı arasında pozitif ve yüksek düzeyde bir ilişkinin $(r=.700)$ olduğu, diğer değişkenlerin kontrol edilmesi halinde iki değişken arasındaki korelasyonun $r=.668$ olarak hesaplandığı görülmektedir. Aile içi ilişkisellik puanı ile arkadaştan sağlanan destek puanı arasında pozitif ve düşük düzeyde bir ilişkinin ( $r=.245)$ olduğu, ancak diğer değişkenlerin kontrol edilmesi durumunda iki değişken arasındaki korelasyonun $r=-.080$ olarak hesaplandığı görülmektedir. Aile içi ilişkisellik puanı ile özel bir insanda sağlanan destek puanı arasında anlamlı bir ilişkinin olmadığı görülmüştür.

Tablo 5.

Kuşaklararası otoritenin yordanmasına ilişkin çoklu regresyon analizi sonuçları

\begin{tabular}{|c|c|c|c|c|c|c|c|}
\hline Değişken & B & $\begin{array}{r}\text { Standart } \\
\text { Hata }\end{array}$ & B & $T$ & $P$ & ikili $r$ & Kısmi r \\
\hline Sabit & 3,369 & 126 & & 26,694 & ,000 & & \\
\hline Aileden sağlanan destek &,- 110 & 021 &,- 225 & $-5,320$ & ,000 &,- 231 &,- 200 \\
\hline Arkadaştan sağlanan destek &,- 010 & 021 &,- 022 &,- 494 & ,621 &,- 113 &,- 019 \\
\hline $\begin{array}{l}\text { Özel bir insandan sağlanan } \\
\text { destek }\end{array}$ &, 003 & ,013 & 010 &, 226 & ,821 &,- 084 & ,009 \\
\hline$R=.231 \quad R^{2}=.053$ & & & & & & & \\
\hline
\end{tabular}


Tablo 5 incelendiğinde kuşaklararası otoritenin yordanmasına ilişkin kurulan regresyon modelinin anlamlı olduğu görülmüştür $(F(3,680)=12.808, p<.001)$. Başka bir ifadeyle algılanan sosyal destek puanları birlikte, kuşaklararası otorite puanını anlamlı olarak yordamaktadır. Aileden sağlanan destek, arkadaştan sağlanan destek ve özel bir insandan sağlanan destek puanları birlikte kuşaklararası otorite puanındaki değişimin \% 5'ini açıklamaktadır ( $R=.231 ; R 2=.053 ; p<.001)$.

Tablo 5 'te yer alan ikili ve kısmi korelasyonlar incelendiğinde, kuşaklararası otorite puanı ile aileden sağlanan destek arasında negatif ve düşük düzeyde bir ilişkinin ( $r=-.231)$ olduğu, diğer değişkenler kontrol edildiğinde iki değişken arasındaki korelasyonun $r=-.200$ olarak hesaplandığı görülmektedir. Kuşaklararası otorite puanı ile arkadaştan sağlanan destek ve özel bir insandan sağlanan destek puanları arasında anlamlı bir ilişki olmadığı görülmüştür.

Tablo 6.

Bilişsel uyumun yordanmasına ilişkin çoklu regresyon analizi sonuçları

\begin{tabular}{|c|c|c|c|c|c|c|c|}
\hline Değişken & B & $\begin{array}{r}\text { Standart } \\
\text { Hata } \\
\end{array}$ & B & $T$ & $\boldsymbol{P}$ & ikili $r$ & Kısmi r \\
\hline Sabit & 2,025 & 133 & & 15,238 & ,000 & & \\
\hline Aileden sağlanan destek & ,296 & 022 & ,520 & 13,564 & 000 & ,450 & ,461 \\
\hline Arkadaştan sağlanan destek &,- 077 & 022 &,- 139 & $-3,486$ & ,001 & ,069 &,- 133 \\
\hline $\begin{array}{l}\text { Özel bir insandan sağlanan } \\
\text { destek }\end{array}$ &,- 010 & ,014 &,- 029 &,- 737 & ,461 & ,102 &,- 028 \\
\hline $\begin{array}{lr}R=.471 & R^{2}=.222 \\
F_{(3,680)}=64.575, & p=.000\end{array}$ & & & & & & & \\
\hline
\end{tabular}

Tablo 6 incelendiğinde bilişsel uyumun yordanmasına ilişkin kurulan regresyon modelinin anlamlı olduğu görülmüştür $(F(3,680)=64.575, p<.001)$. Başka bir ifadeyle algılanan sosyal destek puanları birlikte, bilişsel uyum puanını anlamlı olarak yordamaktadır. Aileden sağlanan destek, arkadaştan sağlanan destek ve özel bir insandan sağlanan destek puanları birlikte bilişsel uyum puanındaki değişimin \% 22'sini açıklamaktadır ( $R=.471 ; R 2=.222 ; p<.001)$.

Tablo $6^{\prime}$ da yer alan ikili ve kısmi korelasyonlara bakıldığında, bilişsel uyum puanı ile aileden sağlanan destek arasında pozitif yönlü ve orta düzeyde bir ilişkinin ( $r=.450)$ olduğu, diğer değişkenler kontrol edildiğinde iki değişken arasındaki korelasyonun $r=.461$ olarak hesaplandığı görülmektedir. Bilişsel uyum puanı ile arkadaştan sağlanan destek arasında pozitif yönlü ve düşük düzeyde bir ilişkinin $(r=.069)$ olduğu, diğer değişkenler kontrol edildiğinde iki değişken arasındaki korelasyonun $r=-.133$ olarak hesaplandığı görülmektedir. Bilişsel uyum ve özel bir insandan sağlanan destek puanları arasında anlamlı bir ilişki olmadığı görülmüştür.

\section{Tartışma, Sonuç ve Öneriler}

Covid-19 salgını bireylerin yaşamında değişiklikler yaratan, bireylerin yaşam biçimlerinde farklı ögelerin var olmasına yol açan bir süreç olarak ele alınabilir. Özellikle sosyal mesafe ve sosyal izolasyon, bireylerin ihtiyaç duyduğu sosyal desteği elde etmede zorluklar oluşturmuştur. Bireyler pandemi sürecinde aile üyeleri ile uzun zamanlar geçirmek dışarıdaki sosyal gruplarla ilişkillerini sınırlamak durumunda kalmışlardır. Bu çalışmada Covid-19 pandemi süreci yetişkinler açısından sosyal destek algısı ve aile iklimi ilişkisi açısından değerlendirilmeye çalışılmıştır. Çalışma grubunun çoğunluğunu kadınlar oluşturmaktadır. Evli ve bekâr bireylerin oranları birbirine yakındır. Aileden sağlanan destek, arkadaştan sağlanan destek, özel bir insandan sağlanan destek, aile içi ilişkisellik ve bilişsel uyum ortalama puanlarının ise katılımcıların cinsiyetlerine göre anlamlı bir şekilde farklılaşmadığı görülmüştür. Covid-19 sürecinde Çin'de yaşayan bireylerin psikolojik semptomlarını incelemek 
amacıyla yapılan başka bir çalışmada da kadınlarla erkekler arasında psikolojik semptomlara sahip olmak açısından anlamlı bir fark bulunmamıştır (Tian, Li Tian, Yang, Shao, \& Tian, 2020). Alanyazın incelendiğinde Altay ve Avcı (2009) yaptıkları çalışmada aileden algılanan sosyal desteğin, cinsiyete göre farklılaşmadığını rapor etmiştir. Turgut (2019) tarafından gerçekleştirilen araştırmada ise aile ikliminin bilişsel uyum alt boyutunun cinsiyete göre farklılaşmadığı ifade edilmişken, aile içi ilişsisellik ve kuşaklararası otorite alt boyutlarının cinsiyete göre farklılaştığı belirtilmiştir. Tonsing vd., (2012) 131 erkek 160 kadın katılımcıyla çok boyutlu algılanan sosyal destek ölçeğinin psikometrik özelliklerini değerlendirmek amacıyla gerçekleştirdikleri çalışmada, algılanan sosyal desteğe ilişkin alt boyutların cinsiyete göre farklılaşmadığını ifade belirtmişlerdir.

Pandemi, fiziki sağlık sorunları kadar toplum üzerinde psiko-sosyal bir etki yaratma potansiyeline sahip görülmektedir ((Subramanian, Gupte, Dorairaj, Periannan \& Mathai 2009). Bu konuda yapılan çalışmalarda bireylerin, akraba ve arkadaşlara bağlanarak sosyal destek arayarak çeşitli baş etme stratejilerine başvurdukları ifade edilmektedir (Folkman ve Lazarus, 1980; Ysseldyk, vd. 2011). Bu çalışmada da evli bireylerin algılanan sosyal destek ve aile iklimi açısından daha yüksek puanlara sahip oldukları görülmüştür. Çeşitli araştırmalardan elde edilen bulgular, bireyin algıladığı sosyal destek kaynaklarının, özellikle aile sosyal desteğinin kaygı için güçlü koruyucu faktörlerden biri olduğunu ve bireyler için destek kaynaklarının mevcut olduğu inancını pekiştirdiğini belirtmektedir (Roohafza, 2014; Yasin ve Dzulkifli, 2010). Bu araştırmada da Aile İklimi Ölçeği ve Algılanan Sosyal Destek Ölçeği'nin tüm alt boyutlarından elde edilen puanlar arasında pozitif yönde anlamlı ilişkilerin olduğu saptanmıştır. Yukarıdaki araştırma verilerini desteleyecek şekilde bireylerin sosyal destek algılarının varlı̆̆ının aile iklimi ile ilişkili olduğu düşünülebilir.

Aile iklimi ölçeğinin alt boyutlarının (aile içi ilişkisellik, kuşaklar arası otorite, bilişsel uyum) bireyin çevresinden (aile, arkadaşlar, özel biri) algıladığı sosyal destek tarafından farklı oranlarda yordandığı görülmektedir. Bu sonuç ailenin önemli sosyal destek kaynaklarından biri olduğunu göstermekle beraber, alanyazındaki sosyal destek ihtiyacı için bireylerin akraba ve akranlarının sosyal ve duygusal desteğine başvurmaları ve aile üyeleriyle daha fazla zaman geçirmeleri intiyacını belirten (Cullen, Gulati ve Kelly, 2020) çalışmalar ve halk sağlığı krizlerinde ruh sağlığı sorunları ile bireylerin sahip olduğu sosyal sermaye düzeyinin arasında negatif bir korelasyon olduğunu sonucuna ulaşan çalışmalar ile paralellik göstermektedir (Noel, Cork ve White, 2018).

2020'de Çin'deki 194 şehirden 1210 katılımcının katıldığı bir çalışma, ankete katılanların \% 54'ünün Covid-19 salgınının psikolojik etkisini orta veya şiddetli olarak değerlendirdiği, \% 29'u orta ila şiddetli anksiyete semptomları bildirdiği ve\% 17'si orta ila şiddetli depresif semptomlar görüldügü bulunmuştur (Cullen vd., 2020). Bu kadar geniş ölçülerde etkisi olabilen pandemi sürecinde bireyin psiko-sosyal yapısını desteklemekte kısa ve uzun vadeli yararlar olduğu düşünülebilir. Ülkemizde de bu süreçte çocuklar ve gençler için yazılan yardım kitaplarında özellikle aile bireylerin salgınla ilgili yaklaşımları ve aile ile birlikte yapılabilecek etkinlikler üzerinde durulmaktadır (Ercan, ArmanRodopman, İnal-Emiroğlu, Öztop \& Yalçın, 2020). Salgın sürecinde ergenlerin psikolojik ihtiyaçları açısından aile ortamı önemli bir belirleyici olarak saptanmıştır (Arı, 2020).

Bu çalışmanın sonuçları pandemi süreci gibi halk sağlığı sorunlarında alınan fiziki önlemler kadar, bireylerin psiko-sosyal sağlıkları açısından algıladıkları sosyal desteğin önemini ve en temel sosyal destek kaynağının aile olduğunu vurgulamak açısından önemli kabul edilebilir. Araştırma sonuçları çerçevesinde; çalışmanın farklı yaş grupları ile yapılması, aile iklimi ve sosyal destek algıları psikolojik sağlamlık, öz-yeterlilik gibi başka değişkenlerle de çalışılması, pandemi sonrası izleme çalışmalarının yapılması, sosyal destek algısının artııılması için ailelere yönelik çalışmaların düzenlenmesi yararlı olabilir. 


\section{Kaynakça}

Akdağ, F. G. ve Çankaya, Z. C. (2015). Evli bireylerde psikolojik iyi oluşun yordanması. Mersin Üniversitesi Eğitim Fakültesi Dergisi, 11(3)-646-662.

Altay, B., ve Avci, ì. A. (2009). Samsun alanlı köyünde yaşayan yaşlılarda aileden algılanan sosyal destek ile depresif belirti yaşama sıklığı arasındaki ilişki. TAF Preventive Medicine Bulletin, 8(2).

Arı, F. A. (2020). Adolescents' psychological needs and perceived family atmosphere during the covid-19 epidemic process. Türk Psikolojik Danışma ve Rehberlik Dergisi, 10(59), 565-579.

Büyüköztürk, Ş., Çakmak, E. K., Akgün, Ö. E., Karadeniz, Ş. ve Demirel, F. (2017). Bilimsel araştırma yöntemleri. Ankara: Pegem Akademik.

Brewin, C. R., Andrews, B. ve Valentine, J. D. (2000). Meta-analysis of risk factors for posttraumatic stress disorder in trauma-exposed adults. Journal of Consulting and Clinical Psychology, 68(5), 748-766. doi: https://doi.org/10.1037/0022-006X.68.5.748.

Cullen, W., Gulati, G. ve Kelly, B. D. (2020). Mental health in the Covid-19 pandemic. QJM: An International Journal of Medicine, 113(5), 311-312. doi: https://doi.org/10.1093/qjmed/hcaa110.

Çepni, S. (2010). Araştırma ve proje çalışmalarına giriş. Trabzon: Yazarın kendi yayını.

Devoldre, I., Davis, M. H., Verhofstadt, L. L. ve Buysse, A. (2010). Empathy and social support provision in couples: Social support and the need to study the underlying processes. The Journal of Psychology, 144(3), 259284.

Eker, D., Arkar, H. ve Yaldız, H. (2001). Çok Boyutlu Algılanan Sosyal Destek Ölçeği'nin Gözden Geçirilmiş Formu'nun faktör yapısı, geçerlik ve güvenirliği. Türk Psikiyatri Dergisi, 12(1), 17-25.

Ercan, E.Ü., Arman-Rodopman, A., İnal-Emiroğlu, N., Öztop, D. B., Yalçın, Ö. (2020). Türkiye çocuk ve genç psikiyatrisi derneği covid-19 (korona) virüs salgını sırasında aile, çocuk ve ergenlere yönelik psikososyal ve ruhsal destek rehberi. Erişim adresi (16.02.2021): http://www.cogepder.org.tr/images/covid-19rehber.pdf.

Folkman, S. ve Lazarus, R. S. (1980). An analysis of coping in a middle-aged community sample. Journal of Health and Social Behavior, 21, 219-239.

Fraenkel, J. R., Wallen, N. ve Hyun, H. H. (2012). How to designande valuate research in education (8. bs.). New York: McGrawHill.

Fydrich, T. \& Sommer, G. (2003). Diagnostik sozialer Unterstützung. In Jerusalem, M. \& Weber, H. (Hrsg.), Psychologische Gesundheitsförderung: Diagnostik und Prävention. Göttingen: Hogrefe.

Gönül, B., Baş, H. I. ve Acar, B. Ş. (2018). Aile İklimi Ölçeği'nin Türkçeye uyarlanması ve psikometrik açıdan incelenmesi. Türk Psikolojik Danışma ve Rehberlik Dergisi, 8(50), 165-200.

Hawryluck, L., Gold, W. L., Robinson, S., Pogorski, S., Galea, S. ve Styra, R. (2004). SARS control and psychological effects of quarantine, Toronto, Canada. Emerging Infectious Diseases, 10(7), 1206-1212.

Karasar, N. (2005). Bilimsel araştırma yöntemi. (15. bs.). Ankara: Nobel Yayın Dağıtım.

Lakey, B. ve Cronin, A. (2008). Low social support and major depression: Research, theory and methodological issues. K. S. Dobson ve D. J. A. Dozois (Ed.), Risk factors in depression (s. 385-408) içinde. Şehir: Elsevier.

Noel, P., Cork, C. ve White, R.G., (2018). Social capital and mental health in post-disaster/conflict contexts: A systematic review. Disaster Med. Public Health Prep. 12, 791-802.

Öztürk, N. (2017). Üniversite öğrencilerinin algıladıkları aile iklimi ve anne-babaya bağlanma biçimleri ile özgüven düzeyleri arasındaki ilişkinin incelenmesi. The Journal of International Lingual Social and Educational Sciences, 3(1), 9-22.

Patterson, J. M. (1992). Promoting resilience in families experiencing stress. Pediatric Clinics of North America, $42,47-63$

Pengilly, J. W. ve Dowd, E. T. (2000). Hardiness and social support as moderators of stress. Journal of Clinical Psychology, 56(6), 813-820.

Roohafza, H. R., Afshar, H., Keshteli, A. H., Mohammadi, N., Feizi, A., Taslimi, M. ve Adibi, P. (2014). What's the role of perceived social support and coping styles in depression and anxiety? Journal of Research in Medical Sciences: The Official Journal of Isfahan University of Medical Sciences, 19(10), 944-949.

Subramanian, T., Gupte, M. D., Dorairaj, V. S., Periannan, V. ve Mathai, A. K. (2009). Psycho-social impact and quality of life of people living with HIV/AIDS in South India. Aids Care, 21(4), 473-481.

Terzi, Ş. (2008). Üniversite öğrencilerinin psikolojik dayanıklılıkları ve algıladıkları sosyal destek arasındaki ilişki. Türk Psikolojik Danışma ve Rehberlik Dergisi, 3(29), 1-11. 
Tian, F., Li, H., Tian, S., Yang, J., Shao, J., \& Tian, C. (2020). Psychological symptoms of ordinary Chinese citizens based on SCL-90 during the level I emergency response to COVID-19. Psychiatry research, 288, 112992. https://doi.org/10.1016/j.psychres.2020.112992 Tonsing, K., Zimet, G. D., ve Tse, S. (2012). Assessing social support among South Asians: The multidimensional scale of perceived social support. Asian journal of psychiatry, 5(2), 164-168.

Turgut, T. (2019). Üniversite öğrencilerinde aile iklimi ve iyi oluş arasındaki ilişkide benlik kurgularının aracı rolünün incelenmesi. (Yayımlanmamış doktora tezi), Marmara Üniversitesi, Enstitü, İstanbul.

von Lieres, S. (2013). Tsunami in Kerala, India: Long-Term Psychological Distress, Sense of Coherence, Social Support, and Coping in a Non-Industrialized Setting. Bern, Switzerland: Peter Lang D. https://www.peterlang.com/view/title/14688 adresinden 15.01.2021 tarihinde ulaşılmıştır.

World Health Organisation [WHO] $(2020,04)$. WHO coronavirus disease (COVID-19) dashboard. Erişim Adresi (05.04.2021): https://covid19.who.int/.

Yasin, A. S. ve Dzulkifli, M. A. (2010). The relationship between social support and psychological problems among students. International Journal of Business and Social Science, 1(3), 110-116.

Ysseldyk, R., Matheson, K. ve Anisman, H. (2011). Coping with identity threat: The role of religious orientation and implications for emotions and action intentions. Psychology of Religion and Spirituality, 3(2), 132148. doi: https://doi.org/10.1037/a0021599. 